\title{
Heroin detoxification during pregnancy: A systematic review and retrospective study of the management of heroin addiction in pregnancy
}

\author{
K V Gilfillan, ${ }^{1}$ FCPsych, MMed (Psych); L Dannatt, ${ }^{2}$ FCPsych, MMed (Psych); D J Stein, ${ }^{2,3}$ FRCPC, PhD; B Vythilingum, ${ }^{1,2}$ FCPsych, MMed (Psych) \\ ${ }^{1}$ Kenilworth Clinic, Cape Town, South Africa \\ ${ }^{2}$ Department of Psychiatry and Mental Health, Faculty of Health Sciences, University of Cape Town, South Africa \\ ${ }^{3}$ Medical Research Council Unit on Risk and Resilience in Mental Disorders, Department of Psychiatry and Mental Health, Faculty of Health \\ Sciences, University of Cape Town, South Africa
}

Corresponding author: L Dannatt (lisa.dannatt@uct.ac.za)

\begin{abstract}
Background. There is general consensus that methadone maintenance is the gold standard in the management of pregnant heroin users. However, in South African state hospitals, methadone withdrawal is the routine procedure offered to these patients, as methadone maintenance programmes are unavailable in the public sector.

Objectives. To conduct a systematic review of the literature on heroin detoxification in pregnancy, and to document pregnancy outcomes in heroin users detoxified with methadone at Groote Schuur Hospital (GSH), Cape Town, from 2006 to 2010.

Methods. A literature search was undertaken to identify key publications on the management of heroin addiction in pregnancy. Patients for the study were identified from the GSH methadone registry, and data were collected from the clinical files.

Results. A total of 20 relevant publications were identified and reviewed. Early case reports described an increased risk of stillbirths and fetal distress after methadone detoxification, but more recent case series involving larger numbers of patients showed positive outcomes. In our study, six pregnant patients received methadone withdrawal over a 5-year period at GSH, and all the neonates had good Apgar scores and were discharged home within 3 days of delivery.

Conclusions. There is limited evidence on the management of heroin addiction during pregnancy, and the only two guidelines identified suggest that methadone maintenance is preferable to methadone withdrawal. The favourable pregnancy outcomes in this small sample of patients managed with methadone withdrawal suggest that it may be safe and deserves further study.
\end{abstract}

S Afr Med J 2018;108(2):111-117. DOI:10.7196/SAMJ.2018.v108i2.7801

Diacetylmorphine was first synthesised by C R Alder Wright in 1874 as a highly potent, acetylated form of morphine. By 1898, Bayer pharmaceutical company marketed this drug under the trademark name of heroin. It was initially sold as a non-addictive morphine substitute and cough suppressant. However, heroin was soon found to be twice as powerful as morphine because it is highly fat soluble and rapidly crosses the blood-brain barrier. Despite subsequent strict controls imposed on the use of heroin, it remains the most widely used opiate. ${ }^{[1]}$

In 2009, there were an estimated 12 - 14 million heroin users worldwide. ${ }^{[1]}$ Europe and Asia remain the key opiate consumption markets, but reports indicate that opiate use in Africa is increasing. ${ }^{[1]}$ The 2010 South African Community Epidemiology Network on Drug Use (SACENDU) statistics reveal that $5-20 \%$ of patients in specialist treatment centres in South Africa (SA) use heroin as their primary illicit drug of choice. In SA, heroin is primarily used by individuals aged $22-30$ years, ${ }^{[2]}$ and $20-40 \%$ of those treated for heroin abuse are female, which is a higher percentage than for most other illicit substances.

Opiate use is associated with menstrual irregularities, which combined with the often erratic lifestyles of drug-abusing women leads to a high rate of unplanned pregnancies. Heroin-dependent pregnant women represent an extremely vulnerable group of patients, who present with various medical, obstetric and psychiatric problems. There has been considerable debate about how best to manage these patients, as the needs of both fetus and mother require careful attention.

The ideal goal during pregnancy is for the mother to abstain from any drug use. When faced with a pregnant patient who is actively abusing heroin, one needs to offer treatment that will best minimise any further fetal and maternal harm. Given the highly addictive nature of opiates, it is difficult for many of these individuals to remain drug free, and some form of maintenance treatment is therefore usually offered.

An alternative to maintenance treatment is opioid withdrawal using methadone. Methadone detoxification involves using tapering doses of methadone to create a smooth transition from heroin use to a drug-free state. Withdrawal from methadone during pregnancy is not generally recommended in the literature, ${ }^{[3-5]}$ except in specific situations such as when a motivated patient expresses a wish to withdraw from all opiates, or when methadone maintenance is unavailable - a state of affairs that is prevalent across all SA public treatment facilities.

Because pregnant women are rarely included in psychotropic clinical trials, relatively little information is available about the use of medication during pregnancy. The evidence-based management of pregnant patients who are dependent on opioids is therefore particularly challenging. While guidance is scarce, the prevailing opinion is that methadone maintenance is the gold standard of treatment in pregnancy. ${ }^{[3-5]}$ This option is not available in SA state 
facilities, where only methadone withdrawal is offered. It is therefore useful to review the data in the literature on the efficacy of methadone withdrawal in pregnancy.

\section{Objectives}

To conduct a systematic review of the literature on heroin detoxification in pregnancy, and to report on pregnancy outcomes of heroin users who were detoxified with methadone at Groote Schuur Hospital (GSH), a teaching hospital in Cape Town, SA, during the 5-year period 2006 - 2010. No cases were noted in the records between 2006 and 2007

\section{Methods}

\section{Systematic review}

The electronic databases PubMed, PsychINFO and the Cochrane Library were searched using a combination of the following search terms: pregnancy, heroin, opiate, methadone, buprenorphine, and treatment. Using the above terms, 14 English articles were located. Of these articles, 5 were relevant to the study. However, by using the article references, a total of 18 relevant articles were found and reviewed.

All relevant articles in English, reporting original data related to the treatment of heroin addiction in pregnancy, were included.

Using the above terms, 12 English articles were located on a PubMed search. Of these articles, 3 were relevant to the study. However, by using the article references, a total of 18 relevant articles were found and reviewed.

\section{Clinical study \\ Location}

GSH is a tertiary state hospital in Cape Town. The patients were managed in the labour ward or in $\mathrm{C} 23$, the emergency psychiatric ward.

\section{Subjects}

The study population included all pregnant heroin-addicted patients who underwent methadone detoxification at GSH between 2006 and 2010 , although the first recorded case was in 2008. The labour ward and C23 keep a register of all patients who have received methadone.

\section{Methadone detoxification at GSH}

A history of substance use is obtained from all patients admitted to maternity, bearing in mind that signs of heroin withdrawal appear within 8 hours after last dose and peak at $36-72$ hours. GSH stocks equity methadone, which contains two milligrams of methadone per millilitre.

Following a positive history for heroin use, symptoms of heroin withdrawal are assessed. These symptoms are assessed using the Objective Opiate Withdrawal Scale (OOWS). This is a 13-item interview and observation tool that assesses for signs of heroin withdrawal.

In pregnant women, $5 \mathrm{mg} / 2.5 \mathrm{~mL}$ of oral methadone is administered if the OOWS score is 3 - 4. In women with an OOWS score of $>4,10 \mathrm{mg} / 5 \mathrm{~mL}$ methadone is given. The OOWS is repeated 2 hours later and further methadone administered as per the above scores. A maximum of $30 \mathrm{mg}$ is administered; however, a doctor may give permission to give top-up doses in severe cases. Once the baseline dose has been established, a total dose of methadone can be given 12-hourly. This is withdrawn slowly.

Further care depends on patient motivation and financial support. Patients who are not motivated to stop using heroin continue methadone during their hospital stay and are referred to a rehabilitation centre to continue motivational interviewing and psychosocial support. Patients who are motivated to stop using heroin can continue detoxification with support and follow-up. For patients who are financially able and willing, maintenance methadone is continued for the duration of the pregnancy.

\section{Data collection}

Pregnant patients treated during the study period were identified by means of information obtained from the methadone register. Both methadone registers were scrutinised carefully to ensure that all pregnant patients treated at GSH were identified. The outcomes of these pregnancies were then determined by looking at specific maternal and fetal parameters as listed in the 'Prospective case series', 'Literature reviews' and 'Case studies' sections of Table 1.

\section{Ethical considerations}

The study was approved by the University of Cape Town Human Research Ethics Committee (ref. no. 072/2010), and permission was granted to access information from the clinical files. Only information relevant to the study was extracted from the patient files, and all the identifying data were kept confidential.

\section{Results}

\section{Systematic review}

A total of 20 relevant articles were found, which were reported in 15 publications. The majority were prospective case series, but others included retrospective case series, case reports, literature reviews and descriptive studies (Table 1 ).

Heroin is not considered to be grossly teratogenic, but it is highly lipophilic and readily crosses the placenta. Untreated heroin use is associated with intrauterine growth restriction, premature delivery, increased neonatal mortality and neonatal abstinence syndrome (NAS), which is characterised by a variety of signs and symptoms in the neonate that indicate dysfunction of the autonomic nervous system, gastrointestinal tract and respiratory system. There is therefore a need for any kind of intervention that will reduce or eliminate maternal heroin use in order to improve pregnancy outcomes.

Maas et al. ${ }^{[8]}$ published an intervention study in 1990 that compared the pregnancy outcomes of mothers joining a methadone detoxification programme with those of mothers who continued uncontrolled street-drug use. They found that 17 out of 58 women successfully completed heroin detoxification during the antenatal period. The incidence of neonatal abstinence syndrome was reduced after maternal participation in the detoxification programme - 55\% v. $88 \%$. Newborns of mothers who had successfully detoxified experienced fewer withdrawal symptoms, and no adverse obstetric complications were reported in this group.

According to most widely accepted recommendations, withdrawal of methadone is not advised before 14 weeks' gestation because of the potential risk of inducing abortion, and should not be performed after the 32nd week of pregnancy because of possible withdrawalinduced stress. ${ }^{[4,5]}$ This view is largely the result of two influential case reports published in the 1970s. Rementeria and Nunag ${ }^{[5]}$ described a stillbirth at term following acute methadone withdrawal, and Zuspan et al. ${ }^{[18]}$ described a case of increased amniotic fluid epinephrine levels during methadone withdrawal, which resolved once the methadone dose was increased.

These initial concerns have since been challenged. In a retrospective study in 2003, Luty et al. ${ }^{[20]}$ reviewed 101 case reports of methadone withdrawal conducted at various stages of pregnancy. They concluded that detoxification treatment was not associated with 


\section{Table 1. Summary of systematic review}

\begin{tabular}{|c|c|c|c|}
\hline Title & Authors & Journal and year & Summary \\
\hline \multicolumn{4}{|c|}{ Literature review and prospective case series } \\
\hline $\begin{array}{l}\text { Adverse neurodevelopmental } \\
\text { outcome of infants exposed to } \\
\text { opiate in utero }\end{array}$ & Hunt et al..$^{[6]}$ & $\begin{array}{l}\text { Early Human } \\
\text { Development, } 2008\end{array}$ & $\begin{array}{l}\text { Review of the literature examining neurodevelopmental } \\
\text { outcome in infants with NAS. } 33 \text { opiate-exposed } \\
\text { infants who were identified after development of NAS } \\
\text { compared with controls. Opiate-exposed infants showed } \\
\text { neurodevelopmental impairment and reduced growth. }\end{array}$ \\
\hline \multicolumn{4}{|l|}{ Prospective case series } \\
\hline $\begin{array}{l}\text { Maternal narcotic abuse and the } \\
\text { newborn }\end{array}$ & Alroomi et al. ${ }^{[7]}$ & $\begin{array}{l}\text { Archives of Disease in } \\
\text { Childhood, } 1988\end{array}$ & $\begin{array}{l}\text { Opiate-exposed infants have higher rates of NAS, } \\
\text { preterm delivery, IUGR and neonatal mortality. }\end{array}$ \\
\hline $\begin{array}{l}\text { Infrequent neonatal opiate } \\
\text { withdrawal following maternal } \\
\text { methadone detoxification during } \\
\text { pregnancy }\end{array}$ & Maas et al. ${ }^{[8]}$ & $\begin{array}{l}\text { Journal of Perinatal } \\
\text { Medicine, } 1990\end{array}$ & $\begin{array}{l}\text { Influence of maternal participation in a methadone } \\
\text { detox programme was compared with street drug use on } \\
\text { neonatal morbidity in } 75 \text { neonates. NAS occurred in } 63 \% \\
\text { of neonates, and was less frequent after methadone detox. }\end{array}$ \\
\hline $\begin{array}{l}\text { Opioid detoxification in } \\
\text { pregnancy }\end{array}$ & Dashe et al. ${ }^{[9]}$ & $\begin{array}{l}\text { Obstetrics and } \\
\text { Gynaecology, } 1998\end{array}$ & $\begin{array}{l}34 \text { pregnant opiate-dependent women offered methadone } \\
\text { detoxification. } 59 \% \text { were successfully detoxified with } \\
\text { no adverse pregnancy outcomes, or relapse to illicit } \\
\text { substances. }\end{array}$ \\
\hline $\begin{array}{l}\text { Methadone maintenance } \\
\text { programme in a Swiss perinatal } \\
\text { centre: Management and outcome } \\
\text { of } 89 \text { pregnancies }\end{array}$ & Kashiwagi et al..$^{[10]}$ & $\begin{array}{l}\text { Acta Obstetricia } \\
\text { et Gynecologica } \\
\text { Scandinavica, } 2005\end{array}$ & $\begin{array}{l}84 \text { pregnant opiate-dependent women offered methadone } \\
\text { maintenance. } 11 \text { attempted detoxification, but } ~ 50 \% \\
\text { returned to maintenance therapy. } 64 \% \text { continued to use } \\
\text { illicit substances while in programme. }\end{array}$ \\
\hline $\begin{array}{l}\text { Methadone maintenance } \\
\text { v. methadone taper during } \\
\text { pregnancy: Maternal and neonatal } \\
\text { outcomes }\end{array}$ & Jones et al. ${ }^{[11]}$ & $\begin{array}{l}\text { American Journal on } \\
\text { Addictions, } 2008\end{array}$ & $\begin{array}{l}175 \text { opioid-dependent pregnant women given methadone } \\
\text { maintenance, methadone withdrawal alone, or } \\
\text { withdrawal followed by maintenance. Given the poor } \\
\text { maternal outcomes with withdrawal alone, maintenance } \\
\text { should be considered as the primary treatment approach. }\end{array}$ \\
\hline $\begin{array}{l}\text { The cost of crime and the benefits } \\
\text { of substance abuse treatment for } \\
\text { pregnant women }\end{array}$ & Daley et al. ${ }^{[12]}$ & $\begin{array}{l}\text { Journal of Substance } \\
\text { Abuse Treatment, } \\
2000\end{array}$ & $\begin{array}{l}\text { Differences in criminal activity were measured in } 439 \\
\text { pregnant women entering five different treatment } \\
\text { programmes. The reduction in crime-related costs was } \\
\text { greatest in residential substance abuse facilities. The cost } \\
\text { of the treatment facility was more than covered by the } \\
\text { cost-saving in crime reduction. }\end{array}$ \\
\hline $\begin{array}{l}\text { Improving treatment outcome } \\
\text { in pregnant opiate-dependent } \\
\text { women. }\end{array}$ & Chang et al. ${ }^{[13]}$ & $\begin{array}{l}\text { Journal of Substance } \\
\text { Abuse Treatment, } \\
1992\end{array}$ & $\begin{array}{l}\text { Outcomes of } 6 \text { pregnant methadone-maintained opiate- } \\
\text { dependent women in an enhanced programme were } \\
\text { compared with those of } 6 \text { women receiving conventional } \\
\text { methadone maintenance. The enhanced-programme } \\
\text { participants had better pregnancy outcomes than the } \\
\text { controls. }\end{array}$ \\
\hline $\begin{array}{l}\text { Management of pregnant drug- } \\
\text { dependent women }\end{array}$ & Finnegan $^{[14]}$ & $\begin{array}{l}\text { Annals of the New } \\
\text { York Academy of } \\
\text { Sciences, } 1978\end{array}$ & $\begin{array}{l}\text { The pregnancy outcomes of } 367 \text { opiate-dependent } \\
\text { women were compared with } 215 \text { non-drug-dependent } \\
\text { women. The groups were further divided into those } \\
\text { receiving an enhanced prenatal programme v. standard } \\
\text { care. Infant mortality was reduced in the opiate- } \\
\text { dependent group in the enhanced programme. }\end{array}$ \\
\hline $\begin{array}{l}\text { Prospective multicentre } \\
\text { observational study of } 260 \text { infants }\end{array}$ & Lejeune et al. ${ }^{[15]}$ & $\begin{array}{l}\text { Drug and Alcohol } \\
\text { Dependence, } 2006\end{array}$ & $\begin{array}{l}\text { Substitution with methadone or buprenorphine improves } \\
\text { pregnancy outcomes. }\end{array}$ \\
\hline
\end{tabular}

born to 259 opiate-dependent mothers on methadone or highdose buprenophine substitution

Literature reviews

Methadone treatment during Wang ${ }^{[16]}$ pregnancy

Treating pregnant women dependent on opioids is not the same as treating pregnancy and opioid dependence

Journal of Obstetric, Gynecologic, and Neonatal Nursing, 1999

Winklbaur et al. ${ }^{[17]} \quad$ Addiction, 2008
Methadone treatment is only beneficial if administered as part of a comprehensive care package.

Use of opioid medication for detox or maintenance should follow established national guidelines, but should be done in a co-ordinated and supportive environment. 


\begin{tabular}{|c|c|c|c|}
\hline Title & Authors & Journal and year & Summary \\
\hline \multicolumn{4}{|l|}{ Case studies } \\
\hline $\begin{array}{l}\text { Narcotic withdrawal in } \\
\text { pregnancy: Stillbirth incidence } \\
\text { with a case report }\end{array}$ & $\begin{array}{l}\text { Rementeria and } \\
\text { Nunag }^{[5]}\end{array}$ & $\begin{array}{l}\text { American Journal } \\
\text { of Obstetrics and } \\
\text { Gynecology, } 1973\end{array}$ & $\begin{array}{l}\text { Description of one patient who had a stillbirth following } \\
\text { third-trimester methadone withdrawal. The authors } \\
\text { therefore caution against methadone withdrawal in the } \\
\text { third trimester. }\end{array}$ \\
\hline $\begin{array}{l}\text { Fetal stress from methadone } \\
\text { withdrawal }\end{array}$ & Zuspan et al. ${ }^{[18]}$ & $\begin{array}{l}\text { American Journal } \\
\text { of Obstetrics and } \\
\text { Gynecology, } 1975\end{array}$ & $\begin{array}{l}\text { Description of one patient who developed increased } \\
\text { amniotic fluid epinephrine levels while undergoing } \\
\text { methadone withdrawal. The authors recommend } \\
\text { avoiding detoxification. }\end{array}$ \\
\hline $\begin{array}{l}\text { Detoxification with } \\
\text { buprenorphine of a pregnant } \\
\text { heroin addict }\end{array}$ & Annitto ${ }^{[19]}$ & $\begin{array}{l}\text { American Journal on } \\
\text { Addictions, } 2000\end{array}$ & $\begin{array}{l}\text { Description of a patient withdrawn successfully } \\
\text { using buprenorphine. The author cautions that more } \\
\text { information is needed regarding buprenorphine } \\
\text { withdrawal. }\end{array}$ \\
\hline \multicolumn{4}{|l|}{ Retrospective case series } \\
\hline $\begin{array}{l}\text { Is opiate detoxification unsafe in } \\
\text { pregnancy? }\end{array}$ & Luty et al..$^{[20]}$ & $\begin{array}{l}\text { Journal of Substance } \\
\text { Abuse Treatment, } \\
2003\end{array}$ & $\begin{array}{l}101 \text { pregnant opiate-dependent women underwent } \\
\text { detoxification at various pregnancy stages. Methadone } \\
\text { detox was not associated with adverse effects in the } \\
\text { second or third trimester. }\end{array}$ \\
\hline $\begin{array}{l}\text { Methadone maintenance in } \\
\text { pregnancy: Consequences to care } \\
\text { and outcomes }\end{array}$ & Edelin et al. ${ }^{[21]}$ & $\begin{array}{l}\text { Obstetrics and } \\
\text { Gynaecology, } 1989\end{array}$ & $\begin{array}{l}\text { Pregnancy outcomes of } 26 \text { narcotic-addicted women } \\
\text { enrolled in a methadone maintenance programme } \\
\text { compared with } 37 \text { polydrug users not in the programme. } \\
\text { No major difference in outcomes found between the two } \\
\text { groups. }\end{array}$ \\
\hline \multicolumn{4}{|l|}{ Descriptive studies } \\
\hline $\begin{array}{l}\text { Detoxification considerations } \\
\text { in the medical management of } \\
\text { substance abuse in pregnancy }\end{array}$ & Allen ${ }^{[22]}$ & $\begin{array}{l}\text { Bulletin of the New } \\
\text { York Academy of } \\
\text { Medicine, } 1991\end{array}$ & $\begin{array}{l}\text { Methadone maintenance has become the mode of } \\
\text { therapy for most patients based on early case reports. }\end{array}$ \\
\hline $\begin{array}{l}\text { The management of heroin } \\
\text { misuse in pregnancy: Time for a } \\
\text { rethink? }\end{array}$ & Mactier ${ }^{[23]}$ & $\begin{array}{l}\text { Archives of Disease in } \\
\text { Childhood, Fetal and } \\
\text { Neonatal Edition, } \\
2011\end{array}$ & $\begin{array}{l}\text { There is increasing evidence of adverse effects upon } \\
\text { developing cortical and visual function in children of } \\
\text { treated heroin-addicted mothers. Studies are needed that } \\
\text { take into account longer-term outcomes for the child. }\end{array}$ \\
\hline \multicolumn{4}{|l|}{ Systematic review } \\
\hline Substance use in pregnancy & Wong et al. ${ }^{[3]}$ & $\begin{array}{l}\text { Journal of Obstetrics } \\
\text { and Gynaecology } \\
\text { Canada, } 2011\end{array}$ & $\begin{array}{l}\text { Review of the literature of substance abuse in pregnancy. } \\
\text { Methadone maintenance recommended owing to } \\
\text { reduced relapse to illicit substances. }\end{array}$ \\
\hline
\end{tabular}

any risk of miscarriage in the second trimester or with premature delivery in the third trimester. Similarly, Dashe et al. ${ }^{[9]}$ conducted a prospective study in which 35 opioid-addicted pregnant patients were offered inpatient opiate detoxification with methadone; $59 \%$ of them successfully completed heroin detoxification, did not relapse, and had no adverse pregnancy outcomes.

Apart from the risk of fetal harm during methadone detoxification, the major concern with not providing long-term methadone treatment is an increased risk of relapse to illicit drug use. There is a perception that mothers engaged in maintenance programmes are less likely than those who are not to use illicit drugs, or to engage in other drug-seeking behaviours such as prostitution.

Wong et al..$^{[3]}$ conducted a literature review of substance abuse in pregnancy in order to provide recommendations on management. They concluded that methadone maintenance treatment is associated with longer adherence to treatment and a decreased risk of relapse to opioid use, and therefore proposed that the preferred standard of care for pregnant opioid-dependent women is substitution therapy.

However, some studies have shown that methadone maintenance treatment does not guarantee abstinence. Kashiwagi et al. ${ }^{[10]}$ explored pregnancy outcomes among women in a major Swiss methadone maintenance programme, and $64 \%$ of the women were found to be co-users of cocaine and/or heroin.

Apart from not always curtailing illicit drug use, management with methadone poses its own risks. Fetal methadone dependence has been associated with fetal death, growth restriction, preterm birth, meconium aspiration and NAS. ${ }^{[7]}$ It has been estimated that $60-87 \%$ of neonates born to methadone-maintained mothers require treatment for NAS. Neonates suffering from NAS grow poorly in the neonatal period, and have reduced height compared with controls at 3 years of age. ${ }^{[12]}$

The longer-term implications of methadone maintenance treatment are also not clear. Hunt et al. ${ }^{[6]}$ conducted a study on infants who had developed NAS, and found that they had evidence of both cognitive and psychomotor deficit on psychometric testing compared with non-opiate-exposed controls. Recent literature has also reported an increased incidence of ocular abnormalities in infants of methadonemaintained mothers. The possibility of long-term visual and cortical defects is alarming, and requires further research.

Methadone withdrawal is the standard management of pregnant heroin addicts in state hospitals in SA. This is largely due to financial constraints, as methadone maintenance management is more costly 
than withdrawal. This concept has, however, been challenged by Daley et al., ${ }^{[12]}$ who suggest that the healthcare costs should not be viewed in isolation. They argue that maintenance treatment reduces maternal criminal behaviour by reducing illicit drug use, which has secondary cost implications for society. The authors conducted a study in Massachusetts, USA, which indicated that the cost of crime far outweighed that of substance abuse treatment.

It seems that medical professionals need to shift the focus of attention from the medical management of cravings and fluctuating maternal opiate levels to providing a more comprehensive care package. Studies conducted by Chang et al.$^{[13]}$ and Finnegan ${ }^{[14]}$ found that methadone maintenance, in addition to intensive antenatal care, is compatible with an uneventful pregnancy and birth of a healthy infant.

\section{The GSH study}

Because methadone is a highly addictive schedule 6 drug, its administration is recorded in a methadone register. This register shows that only six pregnant heroin-addicted patients received methadone detoxification at GSH between 2006 and 2010, although the first case recorded was in 2008. The clinical details of these patients are shown in Tables $2-4$.

A total of six pregnant patients received methadone withdrawal at GSH between 2008 and 2010. Their ages ranged from 17 to 37 years. Four of the six patients were single and one was divorced, and half of them were of high parity. Apart from patient $\mathrm{D}$, all the patients booked late (defined as booking after 20 weeks' gestation). All the patients were HIV-negative, and none had current syphilis infection.

Surprisingly, none of the patients abused alcohol, and patients $\mathrm{B}$ and F were the only two patients who used other substances benzodiazepines and methamphetamine, respectively. All six patients underwent detoxification at some point during their pregnancies, with patients $\mathrm{A}$ and $\mathrm{B}$ requiring detoxification prior to delivery. There was no record of any psychiatric follow-up for any of the patients after detoxification, apart from patient $\mathrm{D}$, who could afford a private rehabilitation facility.

Four of the patients delivered at term, patient B delivered at 33 weeks' gestation following heroin detoxification with methadone, and patient $\mathrm{F}$ delivered spontaneously 1 week short of term. Half of the patients required caesarean section. Patient A required an emergency caesarean section for fetal distress due to placental abruption; however, it was not clear from the records if this was due to her ongoing heroin use or another obstetric cause. Interestingly, all the neonates had Apgar scores ranging from 7 to 10, and none of them required resuscitation. None of the neonates showed signs of NAS. All the patients were discharged from the maternity ward within 3 days after delivery.

\section{Discussion}

After review of the various studies found in the literature, it is apparent that data on the safety and efficacy of methadone detoxification are limited. There are, however, good data on the need to develop comprehensive treatment programmes that go beyond the dispensing of methadone and/or other medication. Pregnancy is often described as a useful period for encouraging behavioural changes. However, methadone alone, whether given as detoxification or maintenance, does not correct underlying psychosocial problems or address behaviour changes. The best outcomes are most likely to be reached by using an integrated care plan incorporating pharmacological, psychotherapeutic and social interventions. The most striking feature of our case series is the relatively low number of patients who received methadone detoxification, despite the rising rates of heroin use and the burden of disease encountered in Cape Town.

Given that the 2010 SACENDU statistics reveal that heroin is the primary substance of abuse among $13 \%$ of substance abusers in the Western Cape Province, ${ }^{[2]}$ it may be speculated that heroin-addicted pregnant patients are inadequately screened for, or are offered detoxification with only benzodiazepines and analgesics. There are two possible explanations for this. Firstly, these patients may face tremendous stigma, not only from their families and society but also from healthcare providers, and they may therefore be treated with little sympathy, being perceived as attempting to manipulate the system by requesting methadone treatment. Secondly, healthcare workers may be concerned about the risk of exposing the fetus to another potentially harmful substance.

Five of the six patients had received methadone detoxification prior to delivery, while patient B went into labour during her withdrawal. Of the five patients who completed their detoxification, three resumed using heroin prior to their delivery, with patient A requiring a second detoxification at the time of delivery. In this small sample, the relapse rate is low given the fact that only one patient received continued psychosocial support after discharge. This low

Table 2. Maternal demographic data

\begin{tabular}{|c|c|c|c|c|c|c|}
\hline & \multicolumn{6}{|c|}{ Patient } \\
\hline & A & B & C & D & $\mathbf{E}$ & $\mathbf{F}$ \\
\hline Age, years & 24 & 37 & 21 & 34 & 17 & 28 \\
\hline Marital status & Divorced & Single & Single & Single & Single & Married \\
\hline Gestation, weeks & $37+$ & 33 & $42+$ & 39 & $38+$ & 36 \\
\hline Obstetric history & G5P2M1SB1 & G1P0 & G1P0 & G5P1M2T1 & G1P0 & G4P3 \\
\hline Blood results & $\begin{array}{l}\text { Rh+ HIV- } \\
\text { VDRL- }\end{array}$ & $\begin{array}{l}\text { Rh+ HIV- } \\
\text { VDRL- }\end{array}$ & $\begin{array}{l}\text { Rh+ HIV- } \\
\text { VDRL- }\end{array}$ & $\begin{array}{l}\text { Rh+ HIV- } \\
\text { VDRL- }\end{array}$ & $\begin{array}{l}\text { Rh+ HIV- } \\
\text { VDRL- }\end{array}$ & $\begin{array}{l}\text { Rh+ HIV- } \\
\text { VDRL- }\end{array}$ \\
\hline Booking, weeks & 29 & 32 & 31 & 11 & 24 & 33 \\
\hline \multicolumn{7}{|l|}{ Antenatal } \\
\hline Visits, $n$ & 8 & 2 & 4 & 5 & 4 & 1 \\
\hline Complications & No & Admitted & No & No & No & No \\
\hline Nicotine use & Yes & Yes & No & No & Yes & Yes \\
\hline Alcohol use & No & No & No & No & No & No \\
\hline Other substance use & Heroin & $\begin{array}{l}\text { Heroin } \\
\text { Benzodiaze }\end{array}$ & Heroin & Heroin & Heroin & $\begin{array}{l}\text { Heroin } \\
\text { Meth }\end{array}$ \\
\hline
\end{tabular}




\begin{tabular}{|c|c|c|c|c|c|c|}
\hline & \multicolumn{5}{|c|}{ Patient } & \multirow[b]{2}{*}{$\mathbf{F}$} \\
\hline & A & B & $\mathrm{C}$ & D & E & \\
\hline \multicolumn{7}{|l|}{$\begin{array}{l}\text { Antenatal management of } \\
\text { heroin use }\end{array}$} \\
\hline Admission (for detox) & Yes & Yes & Yes & Yes & Yes & Yes \\
\hline Place & STH & GSH & GSH & GSH & GSH & GSH \\
\hline Duration & 30 Jun - 7 Sep 2009 & 5 Jun 2008 & 9 - 11 Mar 2010 & $\begin{array}{l}21-23 \mathrm{Apr} \\
2010\end{array}$ & $15-21 \mathrm{Jul} 2010$ & $\begin{array}{l}\text { 9-11 Mar } \\
2010\end{array}$ \\
\hline After detox & No known follow-up & $\begin{array}{l}\text { Labour and } \\
\text { delivery }\end{array}$ & CTDC referral & Private rehab & $\begin{array}{l}\text { STH detox } \\
\text { ward }\end{array}$ & $\begin{array}{l}\text { STH detox } \\
\text { ward }\end{array}$ \\
\hline $\begin{array}{l}\text { Ongoing use of heroin } \\
\text { post detox }\end{array}$ & Yes & No & Yes & No & Yes & No \\
\hline $\begin{array}{l}\text { Admission date to maternity } \\
\text { wards and reason }\end{array}$ & 27 Oct for detox & 5 Jun for detox & $\begin{array}{l}24 \text { May in } \\
\text { labour }\end{array}$ & $\begin{array}{l}16 \text { Jun for } \\
\text { elective } \\
\text { caesarean } \\
\text { section }\end{array}$ & $\begin{array}{l}11 \text { Aug with } \\
\text { pre-labour } \\
\text { ROM }\end{array}$ & $\begin{array}{l}23 \text { Mar in } \\
\text { labour }\end{array}$ \\
\hline Date of last heroin use & 27 Oct & 4 Jun & 22 May & $21 \mathrm{Apr}$ & $28 \mathrm{Jul}$ & 9 Mar \\
\hline $\begin{array}{l}\text { Methadone use during } \\
\text { admission to maternity }\end{array}$ & $\begin{array}{l}28 \text { - } 30 \text { Oct: } 10 \mathrm{~mL} / 20 \mathrm{mg} \\
31 \text { Oct - } 1 \text { Nov: } 8 \mathrm{~mL} / 16 \mathrm{mg} \\
2-3 \text { Nov: } 6 \mathrm{~mL} / 12 \mathrm{mg}\end{array}$ & $\begin{array}{l}9 \text { - } 11 \text { Jun: } \\
8 \mathrm{~mL} / 16 \mathrm{mg}\end{array}$ & None & None & None & None \\
\hline
\end{tabular}

Table 4. Neonatal data

\begin{tabular}{|c|c|c|c|c|c|c|}
\hline & \multicolumn{6}{|c|}{ Patient } \\
\hline & $\mathbf{A}$ & B & $\mathrm{C}$ & D & $\mathrm{E}$ & F \\
\hline \multicolumn{7}{|l|}{ Delivery } \\
\hline Mode & CS & Vacuum & CS & CS & NVD & NVD \\
\hline Indication & AP, FDS & $\begin{array}{l}\text { Spontaneous } \\
\text { labour }\end{array}$ & FDS & Previous CS & Pre-labour ROM & $\begin{array}{l}\text { Spontaneous } \\
\text { labour }\end{array}$ \\
\hline Date & 4 Nov 2009 & 10 Jun 2008 & 25 May 2010 & 16 Jun 2010 & $\begin{array}{l}\text { Pre-labour ROM on } \\
11 \text { Aug 2010, given } \\
\text { oxytocin } \\
\text { NVD } 13 \text { Aug } 2010\end{array}$ & 23 Mar 2010 \\
\hline \multicolumn{7}{|l|}{ Apgar score } \\
\hline $1 \mathrm{~min}$ & $8 / 10$ & $7 / 10$ & $9 / 10$ & $9 / 10$ & $8 / 10$ & $9 / 10$ \\
\hline $5 \mathrm{~min}$ & $10 / 10$ & $9 / 10$ & $10 / 10$ & $10 / 10$ & $10 / 10$ & $9 / 10$ \\
\hline Sex of neonate & $\mathrm{F}$ & M & M & $\mathrm{F}$ & M & $\mathrm{F}$ \\
\hline \multicolumn{7}{|l|}{ Measurements } \\
\hline Birth weight, g & 2200 & 2110 & 3960 & 2600 & 3540 & 3240 \\
\hline Head circumference, $\mathrm{cm}$ & 33 & 34 & 36 & 31 & 33 & 34 \\
\hline Resuscitation & No & No & No & No & No & No \\
\hline NAS & No & No & No & No & No & No \\
\hline \multicolumn{7}{|l|}{ Discharge } \\
\hline Date & $7 \mathrm{Nov}$ & 13 Jun & 28 May & 19 Jun & 14 Aug & $24 \mathrm{Mar}$ \\
\hline Treatment & $\begin{array}{l}\text { Referred to C23, } \\
\text { self-discharge } \\
\text { against advice }\end{array}$ & Diazepam & No meds & No meds & No meds & No meds \\
\hline
\end{tabular}

rate of relapse indicates that methadone detoxification may be a successful way of managing these patients. One of the main criticisms of withdrawal treatment is the high rate of relapse to heroin use, which was shown not to be the case in this small population. This having been said, a relapse rate of $60 \%$ is not negligible, and ideally, further psychosocial measures should be implemented to assist in maintaining abstinence.
A major concern with methadone maintenance treatment is the high risk of NAS. This syndrome is characterised by central nervous system excitability in newborn infants, and in many cases requires pharmacological withdrawal treatment. All the infants of the six patients described were born without showing any sign of opioid withdrawal, had good Apgar scores and required no resuscitation. As mentioned earlier, the literature suggests that NAS requiring 
treatment occurs in at least two-thirds of infants born to mothers on methadone maintenance. The positive neonatal outcome in this group is therefore significant, as it highlights a major advantage of methadone detoxification over maintenance.

Rementeria and Nunag ${ }^{[5]}$ cautioned against detoxification after 32 weeks' gestation owing to concerns about precipitating early delivery. Four of the six patients (A, B, E and F) were detoxified after 32 weeks, with patient $A$ requiring a second detoxification at term, and two of the four (A and B) went into labour during the detoxification process, patient $B$ having premature delivery at 33 weeks. These findings support the view that detoxification is safest during the second trimester.

An interesting finding in these six patients was the low rate of comorbid substance abuse, and the fact that none of them were infected with HIV or with syphilis. This group of patients is usually at high risk for polysubstance abuse and sexually transmitted infections. The absence of these common additional problems may also partly explain the relatively good neonatal outcomes in the group.

The apparent discrepancy in the resources available to heroinaddicted pregnant women in developed countries compared with SA is disheartening. The focus of most research has shifted from determining the merits of maintenance $v$. withdrawal to determining which medication is superior in maintenance management. SA state facilities continue to offer only methadone as substitution medication, and only for a limited period while undergoing withdrawal. This management of heroin withdrawal by detoxification and lack of opiate substitution treatment in government facilities in SA highlights the need for a greater focus on pharmacological harm reduction strategies in low- and middleincome countries.

\section{Study limitations}

The limitations of the current data set include the small sample size, the retrospective ratings, and the lack of any follow-up information. Despite this, however, these data suggest that favourable outcomes of pregnancies managed with methadone withdrawal are possible. Additional research is nevertheless required to confirm these preliminary findings.

\section{Conclusions}

There is limited evidence on the management of heroin addiction during pregnancy, and the only two guidelines identified suggest that methadone maintenance is preferable to methadone withdrawal. The favourable pregnancy outcomes in this small sample of patients managed with methadone withdrawal suggest that it may be safe and deserves further study.
Acknowledgements. DJS is supported by the South African Medical Research Council.

Author contributions. KVG: first author; LD: second author; DJS: second supervisor; BV: primary supervisor.

Funding. None.

Conflicts of interest. None.

1. United Nations Office on Drugs and Crime. World Drug Report 2011, pp. 45-55. https://www.unodc.org/ unodc/en/data-and-analysis/WDR-2011.html (accessed 13 December 2017)

2. Pluddemann A, Dada S, Parry C, et al. Monitoring alcohol \& drug abuse trends in South Africa (July 1996 - December 2009): Phase 27. SACENDU Research Brief 2010;13(1):1-11. http://hdl.handle. net/20.500.11910/3905 (accessed 5 January 2018).

3. Wong S, Ordean A, Kahan M, et al. Substance use in pregnancy. J Obstet Gynaecol Can 2011;33(4):367384. https://doi.org/10.1016\%2Fs1701-2163\%2816\%2934855-1

Fischer G, Bitschau M, Peternell A, et al. Pregnancy and substance abuse. Arch Womens Ment Health 1999;2(2):57-65. https://doi.org/10.1007\%2Fs007370050037

1999;2(2):57-65. https://doi.org/ $10.1007 \% 2 \mathrm{~F} 007370050037$
Rementeria JL, Nunag NN. Narcotic withdrawal in pregnancy: Stillbirth incidence with a case report. 5. Rementeria JL, Nunag NN. Narcotic withdrawal in pregnancy: Stillbirth incidence with a case report.
Am J Obstet Gynecol 1973;116(8):1152-1156. https:///doi.org/10.1016\%2F0002-9378\%2873\%2990953-8 Am J Obstet Gynecol 1973;116(8):1152-1156. https://doi.org/10.1016\%2F0002-9378\%2873\%2990953-8
Hunt RW, Tzioumi D, Collins E, Jeffery HE. Adverse neurodevelopmental outcome of infants exposed to opiate in-utero. Early Hum Dev 2008;84(1):29-35. https://doi.org/10.1016\%2Fj.earlhumdev.2007.01.013 7. Alroomi LG, Davidson J, Evans TJ, Galea P, Howat R. Maternal narcotic abuse and the newborn. Arch Dis Child 1988;63(1):81-83. https://doi.org/10.1136/adc.63.1.81

8. Maas U, Kattner E, Weingart-Jesse B, et al. Infrequent neonatal opiate withdrawal following materna methadone detoxification during pregnancy. J Perinat Med 1990;18(2):111-118. https://doi.org/10.15 5\%2Fjpme.1990.18.2.111

9. Dashe JS, Jackson GL, Olscher DA, et al. Opioid detoxification in pregnancy. Obstet Gynaecol 1998;92(5):854-858. https://doi.org/10.1097\%2F00006250-199811000-00022

10. Kashiwagi M, Arlettaz R, Lauper U, et al. Methadone maintenance program in a Swiss perinatal centre (I): Management and outcome of 89 pregnancies. Acta Obstet Gynecol Scand 2005;84(2):140-144. https:// doi.org/10.1080\%2Fj.0001-6349.2005.00497.x

11. Jones HE, O Grady KE, Malfi D, Tuten M. Methadone maintenance vs methadone taper during Jones HE, O Grady KE, Malf D, Tuten M. Methadone maintenance vs methadone taper during
pregnancy: Maternal and neonatal outcomes. Am J Addict 2008;17(5):372-386. https://doi. pregnancy: Maternal and neo
org/10.1080/10550490802266276

12. Daley M, Argerio M, McCarty D, et al. The cost of crime and the benefits of substance treatment for pregnant women. J Subst Abuse Treat 2000;19(4):445-458. https://doi.org/10.1016/s0740-5472(00)00138-0 13. Chang G, Carroll KM, Behr HM, Kosten TR. Improving treatment outcome in pregnant opiate-dependen women. J Subst Abuse Treat 1992;9(4):327-330. https://doi.org/10.1016/0740-5472(92)90026-k

14. Finnegan LP. Management of pregnant drug-dependent women. Ann N Y Acad Sci 1978;311(1):135-146 https://doi.org/10.1111\%2Fj.1749-6632.1978.tb16770.x

15. Lejeune C, Simmat-Durand L, Gourarier L, Aubisson S. Prospective multicenter observational study of 260 infants born to 259 opiate-dependent mothers on methadone or high-dose buprenophine substitution. Drug Alcohol Depend 2006;82(3):250-252. https://doi.org/10.1016/j.drugalcdep.2005.10.001

16. Wang EC. Methadone treatment during pregnancy.J Obstet Gynecol Neonatal Nurs 1999;28(6):615-622. https://doi.org/10.1111/j.1552-6909.1999.tb02170.x

17. Winklbaur B, Kopf N, Ebner N, Jung E, Thau K, Fischer G. Treating pregnant women dependent on opioids is not the same as treating pregnancy and opioid dependence: A knowledge synthesis for better opioids is not the same as treating pregnancy and opioid dependence: A knowledge synthesis for better
treatment for women and neonates. Addiction 2008;103(9):1429-1440. https://doi.org/10.1111/j.1360treatment for wom

18. Zuspan FP, Gumpel JA, Mejia-Zelaya A, et al. Fetal stress from methadone withdrawal. Am J Obstet Gynecol 1975;122(1):43-46. https://doi.org/10.1016\%2F0002-9378\%2875\%2990613-4

19. Annitto WJ. Detoxification with buprenorphine of a pregnant heroin addict. Am J Addict 2000;9(1):92 97. https://doi.org/10.1080/10550490050172272

20. Luty J, Nikolaou V, Bearn J. Is opiate detoxification unsafe in pregnancy? J Subst Abuse Trea 2003;24(4):363-367. https://doi.org/10.1016/S0740-5472(03)00035-7

21. Edelin KC, Gurganious L, Golar K, Oellerich D, Kyei-Aboagye K, Hamid MA. Methadone maintenance in pregnancy: Consequences to care and outcome. Int J Gynecol Obstet 1989;28(3):311-312. https://doi. org/10.1016/0020-7292(89)90748-0

22. Allen MH. Detoxification considerations in the medical management of substance abuse in pregnancy Bull N Y Acad Med 1991;67(3):270-276. https://www.ncbi.nlm.nih.gov/pmc/articles/PMC1807924/?page=1 (accessed 15 January 2018).

23. Mactier H. The management of heroin misuse in pregnancy: Time for a rethink? Arch Dis Child Fetal Neonatal Ed 2011;96(6):F457-F460. https://doi.org/10.1136/adc.2009.181057 